\title{
REGIONAL DISTRIBUTION OF Fusarium STRAINS IN CORN FROM THE PROVINCE OF SANTA FE, ARGENTINA
}

\author{
(Distribución regional de cepas de Fusarium en maiz en la provincia \\ de Santa Fe, Argentina)
}

\author{
Adriana Saubois*, Marcelo C. Nepote* \& Eduardo Piontelli, ** \\ * Universidad Nacional del Litoral, Facultad de Ingeniería Química, Departamento de \\ Biotecnología, Cátedra de Microbiología. Santiago del Estero 2829, 3000 Santa Fe, Argentina. \\ ** Universidad de Valparaíso, Escuela de Medicina, Cátedra de Micologia. \\ Casilla 92-V, Valparaiso, Chile.
}

Palabras clave: Fusarium, maiz, distribución, Argentina.

Key words: Fusarium, corn, distribution, Argentina

\section{SUMMARY}

Strains of Fusarium isolated from corn havested in differentfields of the nor thern-central area of the province of Santa Fe, Argentina, were identified to the species level. Their distribution in the sampleswas evaluatedand studies of prevalence had to be carried out in conn grains from this region.

Samples of recently hanested and post-harvest dried grains were examined. The isolation of Fusarium strains was performed by direct plating of the grains on polato-dextrose-chloramphenicolagar (PDA $+C A F)$. Afler incubation at room temperature, percentages of grains colonised by the different species were recorded. For the identification of the species, conidial suspensions of monosporic cultures were plated simultancously on PDA and sunthetischer nahrstoffarmer agar (SN.4). Mfacroand microscopic observations were performed after 4,8 and 14 days of incubation at room temperature $\left(22^{\circ}-\right.$ $25^{\circ} \mathrm{C}$.

The prevalence of Fusarium species in the samples was $100 \%$ and $29 \%$ of them was colonized by more than one species. F.moniliforme wasidentified in $52.6 \%$ of the samples, F.subglutinans and F.graminearum, in $29 \%$ and Foxysporum, in 2.6\%. The first speciespresented the highest levels of colonized grains $(7.510 .52 .5 \%$ ).

According to the literature, reports for the different isolated species, we considered convenient to focus future prevalence surveys of Fusarium toxins on twpe B trichoihecenes, zearalenone, moniliformin and fanomisin, in corn grains of this region.

\section{RESUMEN}

Se identificaron a nivel de especie cepas de Fusarium aisladas de granos de maiz provenientes de diferenles campos del área centro-norte de la provincia de Santa $\mathrm{Fe}$, Argentina, estudiandose sudistribución y prevalencia en esta región.

Se examinaron muestras de granos secos de reciente cosecha y almacenados de post-cosecha. El aislamiento de las cepas de Fusarium se llevó a cabo mediante plaqueo directo de los granos en agar papa-dextrosacloranfenicol ( $P D A+C A F)$ yse registraron los porcentajes de granos colonizados por las diferentes especies. Para su identificación, se efectuaron cultivos monospóricos en agor PDA y SNA para inducir la formación de esporodoquios. Se realizaron observaciones macro y microscópicas alos 4,8 y 1 thas de incubación a temperalura ambiente $\left(22^{\circ}-25^{\circ} \mathrm{C}\right)$.

Laprevalencia de Fusarium en las muestras fue del $100 \%$. El $29 \%$ de las mismas secolonizó por más de una especie. Se identificaron F.moniliforme, en el $52.6 \%$ de las muestras, F.subglutinans-F.graminearum, enel $29 \%$, F.oxysporum en el $2.6 \%$. La primera especie, presentó los niveles másaltos de granos colonizados (7.5$52.5 \%$.

Segin los reportes en la literatura, referente a las diferenles especies aisladas, consideramos conveniente orientar posteriores estudios de prevalencia de micotoxinos de Fusurium en granos de maiz de la region. hacia los tricotecenostipo $B$, zearalenona, moniliformina y fumonisina. 


\section{INTRODUCTION}

The genus Fusarium has attracted more altention from a broader range of scientists than possibly any other group of fungi, probably due to the cosmopolitan condition of the group, which is responsible for numerous plant diseases and storage rots $(4,24)$. Fusurium specics are widely distributed in soil and on subterrancous and aerial plant parts, plant debris, and olher organic substrates (3, $7,19)$. They are common in tropical and icmperate regions but also found in deser, alpine and arclic areas (8, 14, 18). The ability of Fusarium species for dispersion in atmosphere making them common colonizers of aerial plant parts, and their ability to cause vascular wilts, root rots and other diseases on a wide range of cereal grains and horticultural crops, explain the reason why they should be considered a threat of conomical importance in agriculure $(6,11,13,22,23)$. Under certainenvironmental conditions in the field as well as during post-harvest stages, the damage caused by certain species of the genus can afred technological properties and nutritional value of grains for human and animal consumption $(11,12,13,19,20$, 23).

In addition to the economical impact of Fusarium infections in agriculture, certain species have been studicd extensively in the last 20 years in relation to the possible role as causative agents of mycotoxicoses. Thereforc, foods and feeds contaminated with their toxins constilute a known risk for human and animal health and have importance in some diseases of unknown ethiology, specially demonstraled for Gibberella zeae (F.grami(nearum) and species in the Section Liscola in relation with rice and corn $(1,16,26,27,34,36)$.

To this respect, there seem to be some gcographical differences in the natural distribution of Fusarium specics, as well as of their corresponding toxins, which are influenced primarily by environmental conditions, crop production and post-harvest handling and storage methods (5).

Biotic, primarily rainfall, abiotic factors, type of cercal cultivar and fungal isolate, may be responsible for the extent of grain infection by Fusarium $(2,21)$.

Com grains have proved to be conmonly invaded and colonized by Fusarium specics in vast arcas of the world under temperate, subtropical and tropical climatc conditions. This crop constitutes an important portion of human and animal diet in Argentina.

National reports concerning the distribution of Fusarium specics present in corn crops are scarce $(9$, $10,17,28,33$ ). Nolwilhstanding, these surveysdo confirm the presence of the Liscola section species (mainly $F$ moniliforme and $F$. graminearum, as wcll as thir teleomorphic states). In these surveys, reforences is made to these species as being responsible fo a fairly signincant diseases which afrects grains of com in their cobs.
Moreover the possible association of com plant infected with $G$. zeae will cases of intoxication in pigs is put forward $(17,28)$. More recent papers $(25,26)$, in the province of B.Aires, revealcd the presence of several species and varicties of Fusarium in arid soils and different cultures of the zone. In con $F$.graminearum, $F$. moniliforme and $F$, oxyspornm were isolated.

Previous data on the distribution of Fusarium spccics in grains of corn harvested in our region have not been made available.

In the present study, Fusarium strains isolated from corn grains were identified to the specics level. Their prevalence and distribution in samples of Santa Fe province, Argentina, were also carried out as a preliminary study focused on future surveys for Fusaritum mycoloxins in cereal of the region.

\section{MATERIALS AND METHODS}

1.-Samples: A lotal of 38 samples of approximatcly 1.000 $-2.000 \mathrm{~g}$ of freshly harvested and recenty post-harvest dried corn grains were collecicd from different ficlds representing the northern-ccutral geographical area of the province of Santa Fe, Argentina. Samples were subdivided in order to oblain portions of analysis of approximately $100 \mathrm{~g}$, and kept in waterproof containers at

Figure 1: Geographical area sampled for Fusarium species distribution in corn grains.
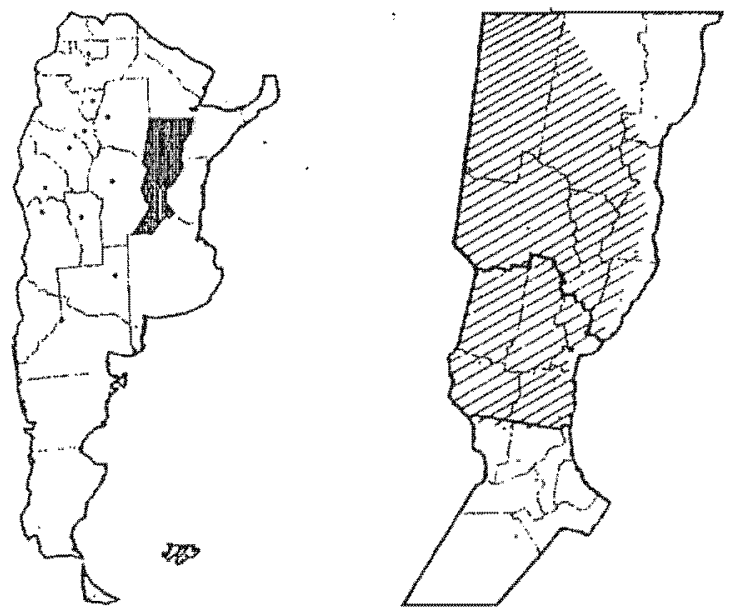

The sampling area is shown as a striped portion in the map. 
$10^{\circ} \mathrm{C}$, until examined. Samples were collected during 1993 crop, and conserved for a maximum period of 6 months. Sampling geographical area is shown in Fig. 1.

2.- Isolation of Fusarium strains: Fifty seeds of each sample were surface sterilized for 2 minutes in $10 \%$ commercial hypochloride, and subsequently washed in four $50 \mathrm{ml}$ sterile water portions. After being dried with sterile paper filter, they were plated on potato-dextrose agar containing $100 \mu g$ of chloramphenicol/ml (PDA +CAF) to suppress bacteria. Five treated seeds were placed on the surface of 10 plates and incubated at room temperature $\left(22^{\circ}-25^{\circ} \mathrm{C}\right)$. Fusurium characteristic colonies growing out from the seeds after 5-7 days were subcultured on PDA slants, simultaneously recording the percentages of colonized seeds.

3.- Single-spore isolation: Single-spore isolation was carried out following Nclson et al. (31). A suspension of conidia was prepared in a $10 \mathrm{~m}$ sterile water portion for each isolation so that it contained a few conidia per drop when observed under low-power microscope field. Each suspension was poured on the surface of a thin laver of solidified $2 \%$ water agar contained in a Petri dish. and the cxcess of water was drained off. After incubation at room temperature. small squares containing single germinating conidia were cul ont and transferred to desircd growth media in order to obtain monosporic cultures for subsequent identification.

4.-Identification of Fusarium strains: Identification of Fusarim strains to the species level was performed following the taxonomic schenes of Gerlach \& Nircmberg (15). Nelson et al. (31). and Puscoc (32). Conidial suspensions of monosporic cultures were inoculated on both PDA and SNA (31), and incubatcd at room tenperature following day-light periods of 12 hours. After 4. 8. and 14 days of incubation. cultures were observed and data of colony pigmentation. lexture and growth rate were recorded, as well as microscopic characteristics such as contdiogenesis, conidigenous cell lypes (mono- and polyphialides, and polyblastic cells). conidium types (macro. micro. meso and chlamydoconidia). conidia grouping lypes. as well as the presenco or absence of sperodoquia and pinnote formations vere recorded.

\section{RESULTS AND DISCUSSION}

Fusarium was detcted in all the 38 corn samples ( $100 \%$ and $29 \%$ of then were coloni/ed by morc than one species. Figures 2 and 3 show the previlence of the different specics and their distribution in the grains. respectively:
Fusarium moniliforme and F.subglutinans (Section Liseola). F.graminearum (Section Discolor), and Faxysporum (Section Elegans), were identified. The firstly named species was prevalent, being present in $71.1 \%$ of the lotal samples, and Faxysporum was detected in only one sample (Table 1). The poor presence of $F$ oxysporum is an incommon situation because it is a soilborne fungus found in agricoltural soils throughout the world and represent an attractive model for the ecological studies of fungal populations. This species also includes pathogenicand non pathogenic strains capable of persisting through asymptomatic colonization of plant roots and saprophytic grow th on non living organic matter. Actually the sapromplitic strains of $F$. oxysporsm are considered success-full biocontrol agents in economically important crops $(7,37)$

F.subglutinums also exhibited rather high levels of colonized grains though its prevalence was lesser than $20 \%$ as it was for F, gramincarum (Table 1). Present data for F.moniliforme are similar to those observed in other agriculural regions conceming maize crop and corn kernel infccion $(2,7,10,17,25,28,33)$. F.monilforne is among the most common Liseola species isolated from the sced of corn. A range of $9 \% 1091 \%$ infection is usually reported for some sced lots of corn (2). In some years, corn kerncls may be $100 \%$ infected by this fungus indicating abiotic faciors, primarily rainfall, might be responsible (2). The association of the fungus on corn kernel is both external and systemic. The nature of the systemic kernel infection is such that seed germination is not necessarily alfected, but rather seedling vigour and growth may be reduced (2).

Table 1: Percentage of corn gratins colonized by Fusurium species

\begin{tabular}{|c|c|c|}
\hline Species & $\%$ Colonived Grains (") & (Mean) \\
\hline F.moniliforme & $8-52.5$ & $(20)$ \\
\hline \multicolumn{3}{|l|}{ Sheldon } \\
\hline Fsubglutimans & $9.8-40$ & $(17.4)$ \\
\hline \multicolumn{3}{|c|}{ (Woll, \&Rein.) Nels, Touss \& Mar. } \\
\hline
\end{tabular}

Scliwabe

Foxysporam $<5$

Schlech, em. Snyd. \& Hans.

(") Maximum and minimum values

Will refercnce to $F$. graminearum, the mechanism of invasion and colonization of corn kerncls seems to be 
Figure 2: Prevalence of Fusarium species in corn grains

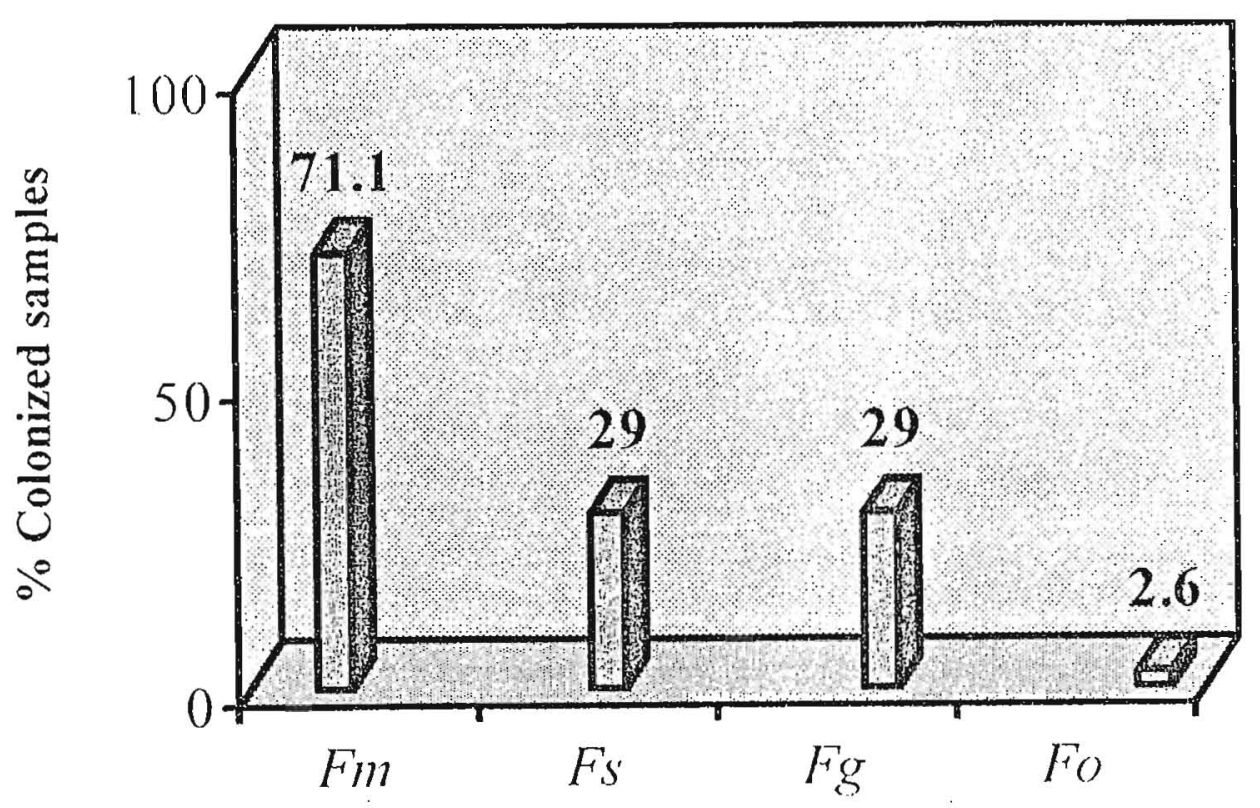

Figure 3. Distribution of Fusarium species in corn grains

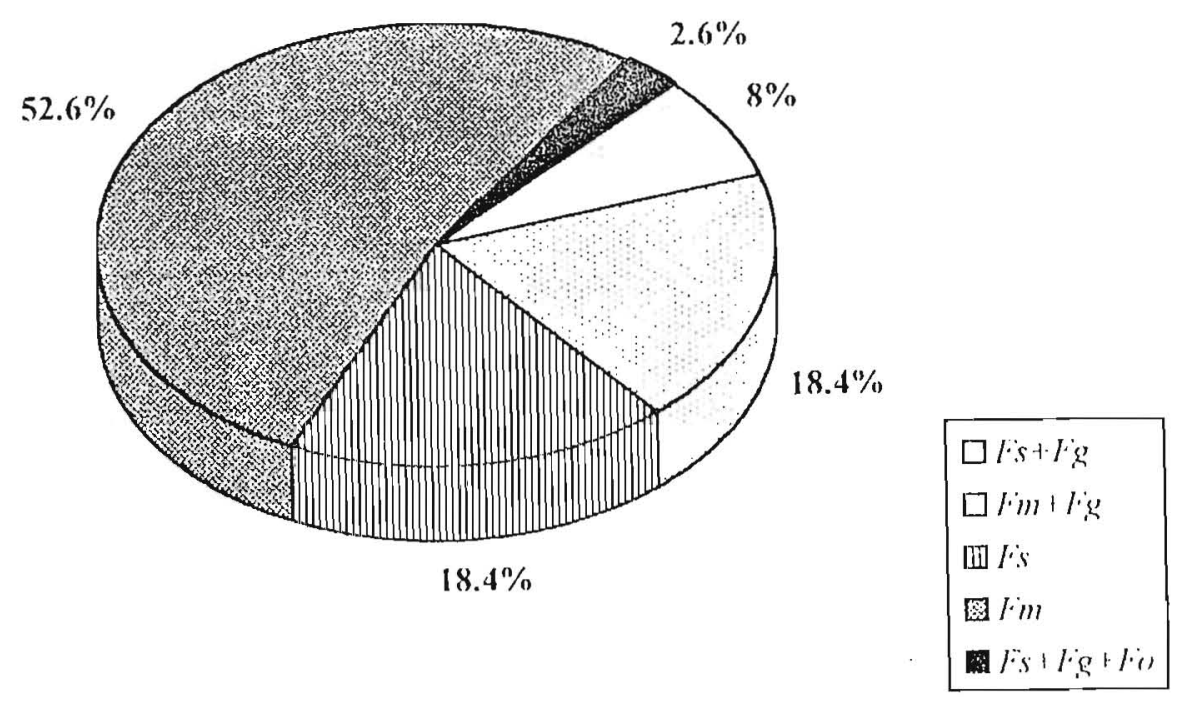

Fim: Fusarium moniliforme Shcldon Fis: Fusarium subglutinans (W. \& R.) Nel., Tous. \& Mar. F"g: Fusarium graminearum Schwabc. Fo: Fusarium oxy'sporum Schlecht. emend. Snyd. \& Hans. 
different from that observed for species in the Section Liscola $(4,7,9,21,22,28)$. Infection is again closely related to rainfall, but insect and bird damage canenhance infection. It could be interesting to point out that there may be a relationship between the occurrence of wheat head blight and maize ear rot epidemics (22).

In reserch works carried out in Argentina, on the presence of Fusarium spccies in several habitats and vegetals, results relate mainly to the phytopathological character of the studies, whereas our study takes in 10 account the relative range of association of the species in the grain lots that enter in to the processing chains.

Reports related with toxigenic ability of Fusarium isolates from different regions in the world suggest a high probability that the crops infected with Fusarium can be contaminated with its loxins (31). This has been paricularly demonstrated for corn. barley and wheat (2.22).

Mycotoxicosis caused by a plant pathogenic fungus produces different secondary metabolites harmful to animals or humans (26). Characteristic profiles of this toxic compound, have been pointed ont to be produced by the different Scctions of the genus, and even by the different species in a Section $(1,22,29.33 .36)$.

With reference to the type of mycotoxins expected to be present. F.graminearum sirains from different geographical areas in the world have been shoun to produce type $B$ trichothecenes. and occasionaly zearalenone $(1,7,9,16,19,25,33,34,35)$. Fumonisins and moniliformin have been found in cultures of strains belonging to Section Liseola, as well as in the original samples of cereals and cereal by products $(2,5,26,27$, 31 ). The last toxins occur frequently in naturally contaminated grains, particularly corn. Although firsty considered field fungi, at present Fusarium species are known to be aclive during storage, and possibly after some stages of cereal technological processing. From this point of view, monitoring of Fusurium toxins should not be restricted to the field nor to the first stages involved in handling crops after harvest.

It should be important to emphasise the prevalence and high percentage of colonization by Fononilforme.

\section{ACKNOWLEDGEMENTS}

This work was supported by grants from the Programme "Curso de Acción para la Investigación y el Desarrollo" - Secretaria de Ciencia y Técnica - Universidad Nacional del Liloral. R. A . and also sponsored by grants from the Fundación Faculiad de Ingenieria Quimica.

We wish to thank Rúben Pantanali for the design and drawing of the figures. Seccion Material Didáctico y Diagramación. Faculiad de Ingenieria Química, Universidad Nacional del Litoral.

\section{REFERENCES}

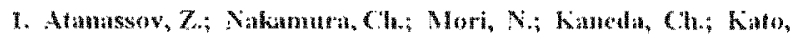

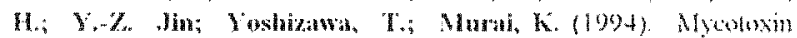
production and pathogenicity of Fotromom species and wheat resistance to Fusarism heald blight Cam. I, 13, 72:161-167

2. Macon, C.W.; Nelson, P.l. (199-4) Jumonisin prodution in com

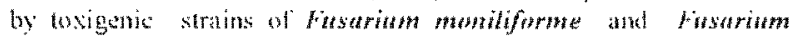
prohlyeratum. I. Food proted. $57: 514-521$

3. Booth, C. (1071). The Gems Finarimn. Commonwall Myological Insitute, Kew, Surrey. England.

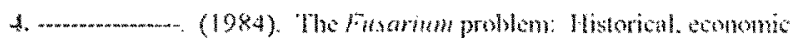
and tasmomic aspeds. In: The applied meolugy of fissarimo.

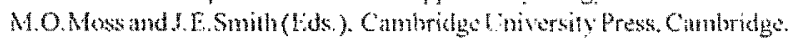

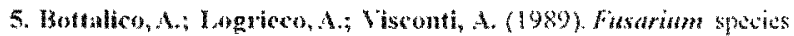
and their mycomins in infected som in laly. Mycopatholngia 107: $85-3) 2$

6. Bulgarelli, M.A.: Brokett, R.F. (1991) The importanes of thugi

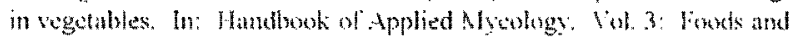

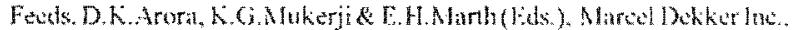
[s.t. pp. 179m104.

7. Murgess, I.W. (1981). General scology of husuria. In: Fusariwn:

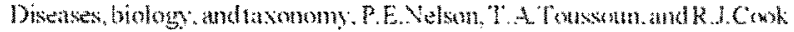

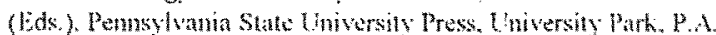

8. Burgess, 1..W.; Nedson, P.W.; Toussom, T.A.; Forbes, G.A. (1988,) Distribution ol fusarium species in Sections Rosenm, Arthosporiella, Gibhosum, and biscolor recowed from grassland. pasture, and pine mursery soils of easiem Australiat. Myeologia $80: 815-824$

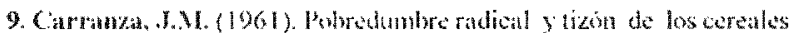

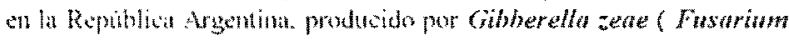
graminearum). Rew lak Agronomia 37:33-58

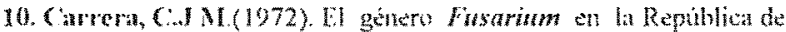
Argemina. Sistematica y considerationes sobre las especies causales de enfenmedades en laplanta. Rew Inv Agric, 11:3-100

11. Cheltuwshi, J. (Wit) (1989). Fusarism. Mycotoxins tawonomy and

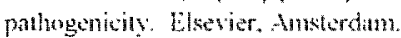

12. - (12) (1991). Cereal Grain. Mycotoxins, Fungi and Quality in Dring and Surage. Elsevier. Ansterdam-London- $N$ Y. Tohio.

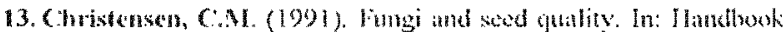

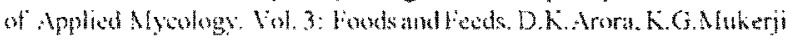

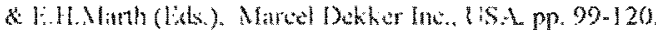

14. Funds, R.G, Burgess, L.W, (1975), Survevs of fusaria and other

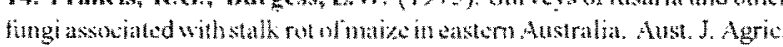
Rex. 26:801.807 
15. Gerlach, W.: Nimenuberg, H. (1982). The Genus Fusarium - A Pictorial Atlas. Mitt. Biol. Bundesanst, Land-Forstwirtsch. Berl.-Da hen.

16. Ichinoe, M.: Kurata, $H_{*}$; Sugina, $Y_{\star}$; Veno, $Y$. (1983). Chemotaxonomy of Gibberella zene with spectal reference produ-ction of trichohecenes and zearatenone. Appl. Environm. Microbiol. 46: 1364 1369

17. Jauch, C. (1960). Entermedades en las espigas del naiz ofusariosis del maiz debido al $F$. monilforme shelon y $F$. monilify me var subglutinus Mem. Técn. Inst, Pat, Vég (INTA) 163:1955-1959

18. Jeschke, N.; Nelson, P.E.; Mamsas, W.F.O. (1900). Fusnrium species isolated from soll samples collected at diflerent alliudes in the Transket, solthem Africa. Mycologia 82:727.733

19. Jome, A.Z. (1986). Fusarim Species: Theirbiology and toxioology Jolu Wiley \& Sons, New Vork-Chichester-Brisbane-Torono-Singapore.

20. Kohl, M.M. (Ed.). (1989). Taller sobre ha fusariosis de la espiga en Anérica dsl Sur. Mexico, D.F.: CNMYT.

21. Kommedhal, $\mathrm{T}$. Windels, C.E. (1981). Rool- stak- and earinfectug Fusarium species on com in the USA. In: Fusariam; Diseases, Biology and Taxonomy. P.E. Nelson, T.A. Toussom ant R.J.Cook (Eds.), The Penusyvanin State University Press, Chiversily Purk, P.A. pp. 94-103.

22. Lacey, J, (1989). Pre- and post-harvest ecology of fung cansing spoiluge of foods and onter stored products. In: Filamenous Fungi in Foods and Feeds, M.O.Moss. B. Jarvis, A. F. A. Skimer(Eds.). The Sociely for Appl. Bacteriol. Symposinn Series No. 18: 115-25S.

23. Lacey, J; Ramakrishua, N, Hamer, A, Magm, N.; Marflect, M.C. (1991), Grain fungi. In: Handbook of Applied Nycology D.K.Aron, K.G.Mukerji, E.H. Marh (E). ), Marcs Dokker Ine, USA pp. 121-177.

24. Liddell C.M1. (1991). Recent advances in Fusarim systematics. Phytopathology 81:1044-1045

25. Lor, C.A. (1985). Género Fusmimm di la Argentima. II Identificacion de especies que alcutan cultivos en la zona de La Plata. Revista Micológica 2; $61-67$

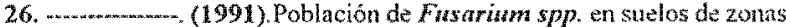
áridas e infuencia del potencial de agua sobre su creeimiento. Revista Argentina de Microbiologia 23:130-137

27. Mamasas, W.F.O.; Nolson, P.E.; Toussoun, T.A. (1984). Toxigenis Fisarim species: Idenity and nycotoxicology. Pennylvania State Unversily Press, Universily Park, P.A

28. Marchonatto, J.1B. (1931). Las fusariosis del trigo y del maiz. Bol. Min. Agric, Nae, $30: 189-191$

29. Nelson, P. E. Desjardins, A. E; Plattner, R.D. (1993). Fumonisins, mycolowins produced by Fusarium species: biology, chemistry, and significance, Aum, Rev.lWylopathol, $31: 233-252$

30. Nelson, R.E.; Toussoum, T.A.; Cook,R.J.(Eds.)(1981). Fusarum, Diseases, biology, and laxomomy. Ponsylvana Slate University lowa, University Park, Pentusylvain, P.A.

31. Nelson, P.E* Toussom, T.A. Mamas, W.F.O. (1983). Fisarim species. An illustrated mamual for identification. The Pemnslvania State Universily Press, University Park and London.

32. Puscoe, 1.G. (1990). Fusminm motphology I: Idenificalion and dianderization of third condial type, the mesocondium. Nycotason 37 : $121-160$

33. Sarasola,A.A. Rocca, M.A.(1981). Enfernuedades y datios sobre naiz, sorgo y girasol en la Argentina. Editorial Hemisferio Sur S.A.

34. Scot, P.N. (1988). Duection of mycoloxins in foods. In: Developnents in Food Mitrobiology-4, R.K. Robinson (Ed.). Ekevior Applied Sticnce, London and New Fork.

35. Sugiuga, $Y .:$ Watanabe, $X_{*}$ T Thaka, T.* Yamamoto, $S_{i}$ Ueno, $Y$. (1990). Occurtence of Cibberella "eae strains that produce both nivalenol and deonyivalenol. Appl. Enviromm Wisobiol. $56: 3047.3051$

36. Ueno, Y. (1287), Trichothecenes in lood In: Mycotoxins in Food, P.Krogh (Ed.), Academic Press, New York, pp. 123-147.

37. Gullmo, M.L.; Migheli, Q.\& Mozahmm, M. (1995). Risk analym sis in the release of biological control agents. Antagonisti $F$ axysom num as a case study, Phut Dizease 79:1193-1201 